\title{
Foreign Aid, Trade Openness and Economic Performance in Sub-Saharan Africa: A Panel Cointegration Investigation
}

\author{
Michael Kwame Asiedu ${ }^{1 *} \quad$ Daniel Ofori ${ }^{2} \quad$ Andrew Akweny $^{3}$ \\ 1. School of Management Sciences \& Law, University of Energy \& Natural Resources, Sunyani \\ 2. Department of Entrepreneurship \& Finance, Kumasi Technical University, Kumasi \\ 3. China Institute for Studies in Energy Policy, School of Management, Xiamen University, China \\ *Corresponding author: asiedumk@gmail.com
}

\begin{abstract}
The objective of this paper was to investigate the impact of foreign aid and trade openness on economic performance for a panel of 30 sub-Saharan African countries over the period 1970-2017 using panel cointegration techniques. The findings obtained in this paper suggest that foreign aid has contributed significantly to economic performance in SSA while trade openness has been detrimental to economic performance during the period under consideration. Also, the combined effect of aid and trade openness has enhanced economic performance. From a policy perspective, the study suggests that more should be done so that the benefits from aid inflows would result in sustained economic performance. Also, the external trade sector should be given the needed attention it deserves.
\end{abstract}

Keywords: aid, trade openness, economic performance, panel cointegration, sub-Saharan Africa

DOI: $10.7176 / \mathrm{DCS} / 12-2-02$

Publication date: February $28^{\text {th }} 2022$

\subsection{Introduction}

The extent to which foreign aid and international trade affect economic performance has been a subject of intense discussion in development literature related to sub-Saharan Africa (SSA) in recent times. This has resulted mainly from the adoption of the structural adjustments and reform programmes of the World Bank and International Monetary Fund by many SSA countries (e.g. Ghana, Nigeria, Burkina Faso, Zambia and Kenya). One feature of these programmes was that they involved large amounts of foreign aid to finance economic activities in SSA. In this regard, sub-Saharan Africa has been the largest recipient of aid with aid rising by $13.6 \%$ reaching US\$34.8billion in real terms in 2016 (OECD, 2017).

One of the key components of the structural adjustment and reform programmes was that the countries involved had to liberalize or open up their economies to international trade. By implication therefore, countries that are more open to international trade would be expected to receive more aid than countries that are less open. Further, it can be hypothesized that donor countries give more aid to countries they have bilateral trade relationship with. Thus, an amount of foreign aid received by a country can be conditioned on the extent to which it has opened up its economy to international trade with other countries especially donors.

Apart from this, international trade has significant effect on aid. International trade is expected to improve the productivity and efficiency of aid. International trade leads to transfer of knowledge resulting in technological progress, enhances efficiency in domestic production and increases market size. If foreign aid enhances capital accumulation and consequently investment, then international trade can make aid become more effective by enhancing the productivity of capital and investment arising from aid through transfer of knowledge and technology. If this holds, then we hypothesize that when foreign aid is interacted with trade openness it could significantly affect economic performance. However, it is unfortunate that the interaction between aid and trade has long been ignored in literature especially those related to sub-Saharan Africa. Most of the existing studies in literature have only estimated the effect of foreign aid on investment and growth with some touching on how the policy environment affects aid effectiveness (For example, Gyimah-Brempong and Racine, 2010; Gyimah-Brempong et al, 2007, Morrissey et al, 2005; Hansen and Tarp, 2000; Burnside and Dollar, 2000). Similarly, trade-growth nexus studies have also sought to specifically find the impact of trade openness on economic growth (See Sakyi et al, 2014; Yanikkaya, 2003; Wacziarg, 2001; Sachs and Warner, 1997).

Studies that specifically focus on the effect of foreign aid and trade openness and their interaction on economic performance in one model seldom exist. In some cases, where they exist, one of them is used as a control variable. Further, a lot of studies in the extant literature use growth rate of GDP rather than per capita GDP (see Gyimah-Brempong and Racine, 2010, Gymah-Brempong et al 2007, Morrissey et al 2005). It is in this regard that this study contributes to the growing literature on the effect of aid and trade on economic performance.

Firstly, it finds out the impact of the interaction between foreign aid and trade openness on economic performance which has long been ignored in literature related to SSA. Secondly, we use aggregate aid data and two measures of aid namely, aid as a percentage of GDP and aid per capita. This enables us to analyse aid- 
economic performance nexus in ways not analysed by previous studies specific to SSA. Third, this study is based on panel data from large number of countries in SSA over a relatively longer period of time, hence the results are more general compared with earlier studies.

The rest of the paper is structured as follows: the second section provides a brief literature review while the third section describes the empirical methodology. The fifth and sixth sections respectively present the empirical results and concluding notes.

\subsection{Aid, trade openness and economic performance - A brief survey}

Within the frameworks of neoclassical and endogenous growth theories, trade openness is very crucial since it can lead to transfer of knowledge and hence technological progress. Openness to international trade promotes technological progress by increasing domestic rivalry and competition, leading to increased innovation. Additionally, trade openness provides the avenue for latest goods to freely flow across international borders. This increases the stock of knowledge for technological innovations which can foster economic activities and improve economic performance (See Keho, 2017; Brueckner and Lederman, 2015; Sakyi et al, 2014; Asiedu, 2013; Yanikkaya, 2003; Wacziarg, 2001; Sachs and Warner, 1997). Apart from this, trade openness (or liberalization) particularly in developing countries comes along with inflow of aid especially since most aids are given to countries with which the donor country has bilateral trade relationship. These aids contribute substantially to capital formation especially in developing countries where levels of savings are generally low. This is expected to enhance economic performance (McGillivray and Morrissey, 1998; Gyimah-Brempong and Racine, 2010; Gyimah-Brempong et al, 2007, Burnside and Dollar, 2000).

Following from the above, there has been a proliferation of studies examining the relationship between foreign aid, trade openness and economic performance. Some of these studies have found positive relationship while others found negative relationship. For example, investigating the effect of aid on growth Morrissey et al (2005) argue that aid affects growth through investment in physical and human capital. Using GMM estimation, they concluded that aid has significantly positive impact on economic growth. Gyimah-Breimpong et al (2010) estimated the impact of aid on growth for a panel of 77 developing countries over the period 1995-2004. Applying dynamic panel data estimator, their results showed that aid has positive effect on growth. Wako (2011) explores the effectiveness of aid on economic growth. He applied the system GMM to a panel of 42 countries from 1980 to 2007 and concluded that there was no evidence that aid and growth are significantly correlated. Balcilar et al., (2018) analyse the interconnectivity of foreign aid and institutions on growth for 39 SSA countries over the period 1996 to 2017. After employing the system GMM technique and controlling for Southern and Eastern Africa, the study found significantly positive correlation between foreign aid and economic growth. Sidiq et al., (2017) examine the impact of foreign aid on economic growth using a panel of countries from South and East Asia. They employed the dynamic panel estimation technique and established from their findings that aid has a significant positive impact on economic growth on condition that there are good policy variables. Galiani et al. (2016) study the effect of aid on growth using a quasi-experiment for 35 countries over the period 1987 to 2010 . Their study revealed a positive relationship between economic growth and foreign aid.

In the case of the trade-growth relationship, Yanikkaya (2003) investigates the effect of trade openness on growth of per capita income for 120 countries over the period 1970-1997 using the Generalized Method of Moment. He concludes that trade openness has significant positive impact on income growth. A study by Sakyi, Villaverde and Maza (2015) for a group of 115 developing countries shows that there is positive bi-directional causal relationship between trade openness and economic growth. Brueckner and Lederman (2015) carry out a study for a sample of 41 countries in sub-Saharan African using the instrumental variable method. Their study concludes that trade openness promotes economic growth both in the short and long run. In his study on the relationship between trade and economic growth, Were (2015) reveals that trade has a significantly positive impact on economic growth in developed and developing countries. Further, they find the impact of trade on economic growth is not statistically significant for least developed countries which essentially comprise African countries. Topall (2016) investigates the connection between trade openness, foreign direct investment and economic growth in the BRICS countries and Turkey by employing unit root and causality tests between 19822013. He finds that there is bi-directional causality between economic growth and trade openness. Keho (2017) estimates the impact of trade openness on economic growth in Cote d'Ivoire by employing ARDL bounds testing approach to cointegration. He finds that trade openness has positive impact on economic growth both in the short and long run situations.

The preceding discussions suggest that the literature on the relationship between foreign aid, trade openness and economic performance have generated mixed results mainly due to econometric technique or data, thereby providing more room for further investigation. It is also evident from the above that the existing studies centre on estimating separately the specific impact of aid and trade openness on economic performance. Clearly, the specific impact of the interaction between aid and trade openness on economic performance is absent. This paper therefore provides further evidence in this area by incorporating the interaction term to account for its effect on 
economic performance.

\subsection{Empirical methodology}

Data and model specification

The panel data consist of annual observations for $30^{1}$ SSA countries for the period 1970 to 2017 . The selection of countries was influenced by data availability for all the variables during the study period.

The major variables of interest in the study are real GDP per capita (a measure of economic performance), trade openness (export plus imports to GDP) and foreign aid (measured by official development assistance and net official assistance). We consider two measures of aid: aid per capita and aid to GDP. Control variables used in the model include foreign direct investment, capital stock, democracy and inflation. All data are obtained from World Bank's WDI Database except democracy which was obtained from Polity IV Project.

\section{Model Estimation}

The specific model to be estimated in this paper takes the following form:

$\log Y_{i t}=\beta_{i}+\theta_{1} A_{I I} D_{i t}+\theta_{2}$ TOP $_{i t}+\theta_{3}(\text { AID } * \text { OPENNESS })_{i t}+\gamma X_{i t}+\mu_{i t} \ldots \ldots . . \quad$ (1)

where $i=1,2,3, \ldots ., N$ represents each individual country, $t=1,2,3, \ldots . ., T$ represents duration for the study, $Y_{i t}$ is the real GDP per capita, AID is foreign aid, TOP is trade openness, $\theta_{1}, \theta_{2}$ and $\theta_{3}$ measure the impact of aid, trade openness and their interaction respectively, $\beta_{i}$ and $\mu_{i t}$ are the country-specific intercept and error term respectively. $X_{i t}$ is a set of control variables which includes foreign direct investment (FDI), capital stock (K), democracy (DEMO) and inflation (INFL).

\section{Panel Unit Root Test}

Unit root test is the initial step in every cointegration investigation. In this paper, the three alternative unit root tests considered were Im-Pesaran-Shan (IPS) test, Levin-Lin-Chu (LLC) test and and Cross-sectionally Augmented Dickey Fuller (CADF) test. Table 1 in the Appendix reports the results of the panel unit root tests.

\section{Panel Cointegration test}

On condition that the variables are stationary, we proceed to estimate the long run relationship among dependent and independent variables. To this end, we make use of Westerlund's (2007) bootstrap-based panel cointegration test. Westerlund (2007) proposed four tests to test for cointegration relationship among the dependent variable and the independent variables. These tests test the null hypothesis of no cointegration against the alternative of cointegration. The cointegration test results as reported in Table 2 in the Appendix show that the estimated models are cointegrated and as such long-run relationship exists among the variables.

\section{Estimation of panel cointegration regression}

Once we establish the existence of cointegration among the variables, we move on to estimate equation (1). We employ the PMG estimator to estimate the long run and short run coefficients. The choice of the PMG estimator over other estimators (such as MG, DOLS, FMOLS, etc.) is due to the fact that the PMG allows the short-run specifications to differ from country to country while it constrains the long run coefficients to be the same. Thus, the PMG estimator ensures that there is homogeneity in the long-run parameters but allows heterogeneity in the short-run parameters. Given these two conditions, PMG provides consistent and efficient estimates. To check for the robustness of the coefficients of the PMG estimator, the Mean Group (MG) is applied.

The PMG estimator proposed by Pesaran et al (1999) assumes an autoregressive distributed lag (ARDL) ( $p$, $\left.q_{1}, \ldots \ldots, q_{k}\right)$ dynamic panel specification of the form:

$y_{i t}=\sum_{j=1}^{p} \lambda_{i j} y_{i, t-j}+\sum_{j=0}^{q} \delta_{i j}^{\prime} X_{i, t-j}+\mu_{i}+\varepsilon_{i t}$

where the number of groups $i=1,2, \ldots ., N$; the number of periods $t=1,2, \ldots ., \mathrm{T} ; X_{i t}$ is a $k \times 1$ vector of explanatory variables; $\delta_{i t}$ are the $k \times 1$ coefficient vectors; $\lambda_{i j}$ are scalars; and $\mu_{i}$ is the group-specific effect. One key feature about cointegrated variables is that they are sensitive to deviation from long run equilibrium. It is therefore imperative to estimate error correction model to capture the short-run dynamics. The resulting error correction equation is thus given in equation (3) below

$$
\Delta y_{i t}=\phi_{i}\left(y_{i, t-1}-\theta_{i}^{\prime} X_{i t}\right)+\sum_{j=1}^{p-1} \lambda_{i j}^{*} \Delta y_{i, t-1}+\sum_{j=0}^{q-1} \delta_{i j}^{*} \Delta X_{i, t-j}+\mu_{i}+\varepsilon_{i t}
$$

\footnotetext{
${ }^{1}$ Benin, Botswana, Burkina Faso, Burundi, Cameroon, Central African Republic, Chad, Democratic Republic of Congo, Republic of Congo, Cote d'Ivoire, Gabon, Ghana, The Gambia, Guinea-Bissau, Kenya, Lesotho, Madagascar, Malawi, Mali, Mauritania, Niger, Nigeria, Rwanda, Senegal, Sierra Leone, Sudan, Swaziland, Togo, Zambia and Zimbabwe.
} 
where $\phi_{i}$ is the error correction term. $\phi_{i}$ is expected to be significantly negative. Also of particular importance is $\theta_{i}^{\prime}$, which contains the long-run relationships between the variables.

\subsection{Results and Discussion}

It is clear from Tables 1 and 2 in the Appendix that the variables in the model are stationary and cointegrated. Consequently, we estimate the long and short run coefficients.

\section{Panel cointegration regression}

In this section, we present and discuss the results of the long and short run coefficients using the PMG estimator. We also apply the Mean Group (MG) estimator to check for robustness of the estimates of the PMG estimator. Clearly, the results from Table 1 show that the MG estimator provides results that are similar to those of the PMG estimator in terms of magnitude and signs of the coefficients, thus demonstrating the robustness of the long and short run estimates.

From Table 1, both measures of aid appear positive and significant in both models (for the PMG estimator) except in the short run where $A I D P C$ was negative albeit not statistically significant. Individually, a percentage rise in $A I D G D P$ enhances economic performance by 0.784 and 0.539 in both the long run and short run respectively while a one percent increase in $A I D P C$ leads to a 0.422 rise in economic performance. A one percent rise in $A I D P C$ leads to a 0.317 decline in economic performance though not significant. Apart from $A I D P C$ in the short run, all the other statistics are statistically significant at $1 \%$ and $5 \%$ levels. These results are consistent with a priori expectation as well as studies that find positive and significant effect of aid on economic performance (Gyimah-Brempong et al, 2010; Karras, 2006; Hansen and Tarp, 2005; Morrissey et al, 2005; Dalgaard et al, 2004; Gomanee, et al., 2003;). It however contradicts other studies such as Brautigman and Knack (2005), Burnside and Dollar (2000) which found negative effect of aid on economic performance. The results obtained in this study are not surprising since individual countries (and for that matter the whole of subSaharan African) have received considerable amount of aid over the period under consideration due to their subscription to the adjustment and reform programmes to help enhance economic performance. Available statistics suggest that the SSA sub-region has been the largest recipient of aid with aid rising by $13.6 \%$ reaching US\$34.8billion in real terms by 2016 .

Table 1 Results of the panel cointegration regression

\begin{tabular}{|c|c|c|c|c|}
\hline Variables & \multicolumn{2}{|r|}{ Model 1} & \multicolumn{2}{|r|}{ Model 2} \\
\hline Long run coefficients & & & & \\
\hline $\ln A I D / G D P$ & $\begin{array}{l}0.784 * * * \\
(0.683)\end{array}$ & $\begin{array}{l}0.531 * * * \\
(0.416)\end{array}$ & & \\
\hline $\ln A I D P C$ & & & $\begin{array}{l}0.422 * * * \\
(0.310)\end{array}$ & $\begin{array}{l}0.537 * * * \\
(0.364)\end{array}$ \\
\hline $\operatorname{lnOPENNESS~}$ & $\begin{array}{l}-0.316^{* *} \\
(0.240)\end{array}$ & $\begin{array}{l}-0.406^{* *} \\
(0.283)\end{array}$ & $\begin{array}{l}-0.324 * * * \\
(0.079)\end{array}$ & $\begin{array}{c}0.281 \\
(0.043)\end{array}$ \\
\hline $\operatorname{lnOPENNESS*AID/GDP}$ & $\begin{array}{l}0.226 * * * \\
(0.052)\end{array}$ & $\begin{array}{l}0.214 * * \\
(0.255)\end{array}$ & & \\
\hline $\begin{array}{l}\ln O P E N N E S S^{*} A I D P C \\
\ln F D I\end{array}$ & & & $\begin{array}{l}0.276^{* * *} \\
(0.046)\end{array}$ & $\begin{array}{l}0.418 * * \\
(0.283)\end{array}$ \\
\hline $\ln K$ & $\begin{array}{l}0.242 * * * \\
(1.034) \\
0.155 * * *\end{array}$ & $\begin{array}{l}0.217 * * * \\
(1.001) \\
0.148 * * *\end{array}$ & $\begin{array}{l}0.236 * * * \\
(1.273) \\
0.214^{* * *}\end{array}$ & $\begin{array}{l}0.225^{* * *} \\
(1.424) \\
0.113^{* *}\end{array}$ \\
\hline$D E M O$ & $\begin{array}{l}(2.435) \\
0.062 * *\end{array}$ & $\begin{array}{l}(1.822) \\
0.057 * *\end{array}$ & $\begin{array}{l}(2.063) \\
0.070 * * *\end{array}$ & $\begin{array}{l}(1.640) \\
-0.052\end{array}$ \\
\hline$I N F L$ & $\begin{array}{l}(0.834) \\
-0.077 * * * \\
(0.681)\end{array}$ & $\begin{array}{l}(0.701) \\
-0.083 * * * \\
(0.516)\end{array}$ & $\begin{array}{l}(0.527) \\
0.067 \\
(0.723)\end{array}$ & $\begin{array}{c}(0.538) \\
-0.086 * * \\
(0.469)\end{array}$ \\
\hline
\end{tabular}




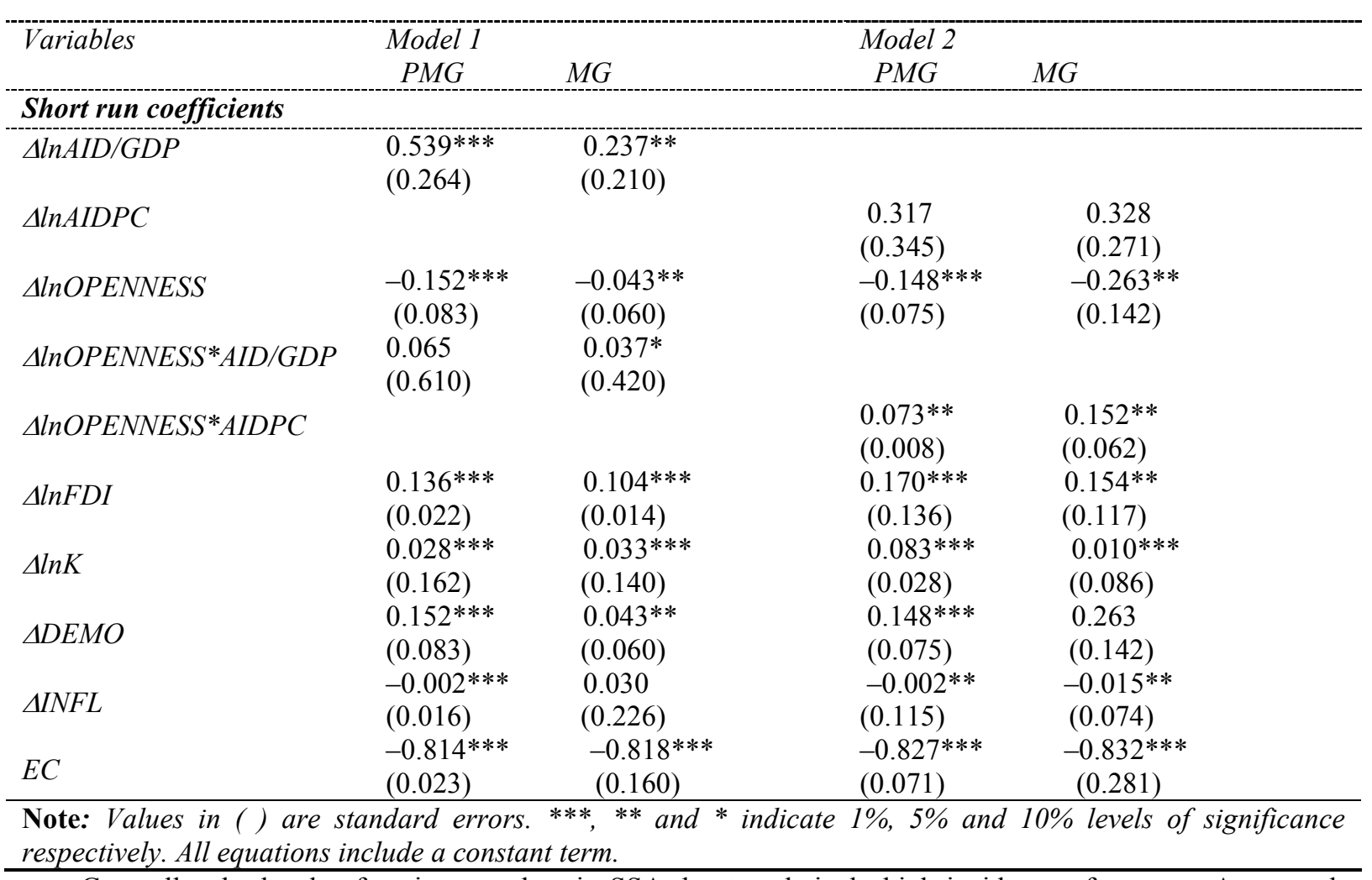

Generally, the levels of savings are low in SSA due to relatively high incidence of poverty. As a result capital formation is very low resulting in low investment and consequently low research and development activities. However, with the rise in foreign aid inflows, it is expected that aid would augment domestic savings to improve domestic capital formation. This would result in increased level of investment and consequently a rise in economic performance.

Contrary to a priori expectation, the coefficients of OPENNESS carry a negative sign in the long run and short run for both measures of aid. For instance, when AIDGDP is used as a measure of aid, a percentage increase in trade openness reduces economic performance by 0.316 and 0.152 in the long run and short run respectively. Similarly, a percentage rise in trade openness leads economic performance to fall by approximately 0.324 and 0.148 in both the long run and short run respectively when AIDPC is used. In all cases, the results are statistically significant at $1 \%$ level except in the long run in model 1 which is at $5 \%$ significance level. This suggests that openness to international trade does not enhance economic peformance in sub-Saharan Africa. Our finding is similar to studies that obtain negative relationship between trade openness and economic performance (Example Akilou, 2013; Gries and Redlin, 2012). However, it is contrary to studies such as Sakyi (2014), Asiedu (2013), Yanikkaya (2003), among others who found positive relationship between trade openness and growth rate of GDP per capita.

Though trade openness is theoretically expected to enhance economic performance through technological transfer from technologically advanced countries, accessibility to larger and wider markets and greater levels of specialization resulting in efficiency among domestic sectors and producers, the results rather suggest that trade openness is detrimental to economic performance. One should however not be surprised. As mentioned earlier, one key feature of the structural and reform programme was trade liberalization which exposed domestic sectors (or producers) to a higher degree of international competition. Unfortunately, these domestic sectors are not able to compete more favourably with their more efficient counterparts in the advanced countries mainly due to their infant nature and also because trade liberalization encourages the importation of cheaper goods. Thus, they produce at a relatively higher average cost, a situation that reduces the productivity in these sectors which subsequently affects economic performance negatively.

Secondly, the negative contribution of trade to economic performance in SSA could be attributed to the unfavourable terms of trade. The exports of many SSA countries are mainly raw primary products (cocoa, minerals, timber, among others) which experience fluctuating prices while the prices of their imports which are mainly manufactured are rising, thereby creating unfavourable terms of trade. Apparently, this result is contrary to the classical argument that openness to trade resulting from comparative advantage enhances economic performance. It however emphasizes the protectionist argument that trade openness has a detrimental effect on the economy.

Clearly, the preceding discussions show that while aid has produced positive effects trade openness has had 
negative impact on economic performance in SSA. Notwithstanding, the combined effect of trade openness and aid (shown by the interaction term) contribute positively to economic performance. From Table 1, when trade openness is interacted with both measures of aid, the coefficients are significantly positive in both the long run and short run at $1 \%$ and $5 \%$ levels of significance. This implies that if trade liberalization (or openness) is a conditionality for receiving aid as in the case of the structural adjustment and reform programmes in SSA and trade openness improves the productivity of aid, then obviously the interaction term would be expected to improve economic performance. Hence, the results suggest that the positive effect of aid exceeds the negative effect of trade openness with regards to their impact on economic performance.

Since trade openness and foreign aid are not the only factors that affect economic performance, we included in our model foreign direct investment, capital stock, political regime and inflation as control variables. With the exception of inflation, the remaining variables have positive and significant impact on economic performance.

The estimated coefficients of the error correction model $(\mathrm{ecm})$ are not only highly significant at $1 \%$ level but also have the appropriate negative sign in both specifications. The coefficients of the ecm as shown in Table 1 reflect a very high speed of adjustment to equilibrium after a shock.

\subsection{Concluding Notes}

The objective of this paper was to investigate the impact of foreign aid and trade openness on economic performance for a panel of 30 sub-Saharan African countries over the period 1970-2017 using panel cointegration techniques. The findings suggest that foreign aid has contributed significantly to economic performance over the period under consideration but trade openness has been detrimental to economic performance in SSA over the same period. Also, the combined effect of aid and trade openness has enhanced economic performance. Additionally, the results show that foreign direct investment, democracy and physical capital stock play a crucial role in economic performance in SSA. Finally, the study finds that inflation is detrimental to economic performance in SSA.

From a policy perspective, the findings obtained in this paper have considerable implications. Even though this paper has established that aid has a statistically significant positive impact on economic performance, it should not be taken to mean aid inflow to SSA has been completely successful. Indeed, when the observed economic performance is compared with aid inflows, it can be seen that it has not. This implies that though the findings suggest that aid has brought some benefits, there is still more room for improvement for these benefits to result in sustained economic performance. More specifically, aid can be channelled to assist small and medium scale businesses which can help to reduce rural and urban poverty. Notwithstanding the positive impact of aid on economic performance, we also recommend that sub-Saharan African countries should gradually reduce their dependence on foreign aid since such assistance are just to complement internal efforts. As shown in this paper, trade openness (or liberalization) adopted as part of the structural reforms has not helped as far as economic performance is concerned. Therefore, policies should target strengthening the external trade sector to make it more competitive. Since the exports section of the external trade generates revenue, policies to make the export sector more competitive relative to the import sector would be more appropriate. This may be achieved through diversification of exports which can be done by adding value to exports so that they attract competitive prices on the world market.

Notwithstanding the above findings, it is significant to emphasize that our paper did not investigate the mechanisms through which foreign aid and trade openness affect economic performance. Secondly, it is also significant to note that aid as used in this paper refers to aggregate aid flows to SSA countries as a percentage of GDP and also per capita during the period of the study. It does not disaggregate aid into loans, grants, food aid, among others. In much the same way, trade openness is also measured as simply the sum of export and import as a percentage of GDP. It is possible that alternative measures can produce different findings.

\section{Appendix}

Table 1 Panel unit root tests results

\begin{tabular}{|c|c|c|c|c|c|c|}
\hline \multirow[b]{2}{*}{ Variables } & \multicolumn{3}{|c|}{ Levels } & \multicolumn{3}{|c|}{ First Difference } \\
\hline & $I P S$ & $L L C$ & $C A D F$ & $I P S$ & $L L C$ & $C A D F$ \\
\hline $\ln G D P P C$ & -1.863 & -2.473 & -1.930 & $22.264 * *$ & $-14.205 * *$ & $-17.753 * *$ \\
\hline $\ln A I D / G D P$ & -3.073 & -3.411 & -2.128 & $-25.102 * *$ & $-12.437 * *$ & $-21.398 * *$ \\
\hline $\ln A I D P C$ & -2.969 & -2.857 & -2.046 & $-21.513 * *$ & $-11.314 * *$ & -20.152 \\
\hline OPENNESS & -2.884 & -3.065 & -2.240 & $-24.349 * *$ & $-13.007 * *$ & $-18.018 * *$ \\
\hline OPENNESS*AID/GDP & -2.915 & -2.822 & -2.148 & $-4.637 * *$ & $-4.865 * *$ & $-3.427 * *$ \\
\hline OPENNESS*AIDPC & -2.532 & -2.763 & -2.381 & $-6.493 * *$ & $-6.704 * *$ & $-5.109 * *$ \\
\hline $\ln F D I$ & -2.471 & -2.100 & -1.217 & $13.662 * *$ & $-10.376^{* *}$ & $-9.118 * *$ \\
\hline $\ln K$ & -1.038 & -1.763 & -1.064 & $-16.468 * *$ & $-13.622 * *$ & $-10.246 * *$ \\
\hline$D E M O$ & -1.315 & -1.244 & -1.702 & $-11.006^{* *}$ & $-8.418 * *$ & $-9.727 * *$ \\
\hline
\end{tabular}


Table 2 Panel Cointegration Test Results

\begin{tabular}{ccc}
\hline Panel Cointegration Tests & Model 1 & Model 2 \\
\hline$G_{\tau}$ & $-8.253^{* * *}[0.002]$ & $-11.841 * * *[0.000]$ \\
$G_{\alpha}$ & $-22.618 * * *[0.000]$ & $-19.324 * *[0.003]$ \\
$P_{\tau}$ & $-15.401 * * *[0.000]$ & $-12.153 * * *[0.001]$ \\
$P_{\alpha}$ & $-18.277 * * *[0.000]$ & $-14.066^{* * *}[0.001]$ \\
\hline
\end{tabular}

Note: Values in [ ] are the robust $\rho$-values. $* * *(* *)$ show significance at $1 \%(5 \%)$

\section{References}

Ahmed, Y. and Anoruo, E. (2000). Openness and Economic Growth: Evidence from Selected Asian Countries. The Indian Economic Journal, 47 (3), 110-117.

Akilou, A. (2013). Is There a Causal Relation between Trade Openness and Economic Growth in the WAEMU Countries? International Journal of Economics and Finance, 5 (6), 151-157

Asiedu, M.K. (2013) Trade Liberalization and Growth: The Ghanaian Experience. Journal of Economics and Sustainable Development, 4 (5), 125-135.

Balcilar, M., Tokar, B. and Olasehinde-Williams, G. O (2018). Examining the interactive growth effect of development aid and institutional quality in Sub-Saharan Africa. Journal of Development Effectiveness 12(1):1-16.

Baltagi, B.H. (2001) Econometric Analysis of Panel Data. $2^{\text {nd }}$ Edition, New York: Wiley \& Sons.

Barro, R. J. (1998), Determinants of Economic Growth: A Cross-Country Empirical Study. Cambridge, MA: MIT Press.

Barro, R.J., \& Sala-i-Martin, X. (2004). Economic growth. $2^{\text {nd }}$ Edition. Cambridge, MA: MIT Press.

Blackburne, E.F. and Frank, M.W. (2007). Estimation of nonstationary heterogeneous panels. Stata Journal, 7 (2), 197-208.

Boone, P. (1995). The Impact of Foreign Aid on Savings and Growth. Working paper No. 677, London School of Economics.

Collier, P. and Dollar, D. (2002) Aid allocation and poverty reduction. European Economic Review, 46 (8), 1475-1500.

Dalgaard, C., Hansen, H. and Tarp F. (2004). On the empirics of foreign aid and growth. The Economic Journal, 114 (496), 191-216.

Dalgaard, C. and Hansen, H. (2005). The Returns to Foreign Aid. Discussion Paper No. 05-04, University of Copenhagen Institute of Economics.

Djankov S., Montalvo J., and Reynal-Querol, M. (2006.) Does foreign aid help? Cato Journal 26 (1), 1-28.

Dollar, D., and Kraay A. (2000). Trade, Growth and Poverty. Working Paper No. 2615, The World Bank Development Research Group, Washington D.C.

Easterly, W. (2003). Can foreign aid buy growth? Journal of Economic Perspectives, 17 (3), $23-48$.

Edwards, S. (1992). Openness, Trade Liberalization and Growth in Developing Countries. Working Paper Series No. 35, Institute for Policy Reform, Washington DC.

Edwards, S. (1998). Openness, productivity and growth: What do we really know? Economic Journal, 10 (8), 383-398.

Fosu, A. K. (1990). Exports and Economic Growth: The African Case. World Development, 18 (6), 831-835.

Frankel, J. A. and Romer, D. (1999). Does trade cause growth? American Economic Review, 89 (3), 379-399.

Galiani, S., Knack, S., Xu, L.C. and Zou, B. (2016). The effect of aid on growth: evidence from a Quasiexperiment. Journal of Economic Growth, 22, 1-33.

Gyimah-Brempong, Racine, J.S. and Gyapong, A. (2010). Aid and Economic Growth: Sensitivity Analysis. Journal of International Development, 10 (1), 7-17.

Gyimah-Brempong, K. (1992). Aid and Growth in LDCs: Evidence from Sub-Saharan Africa, The Review of Black Political Economy, 20 (3), 31-52.

Hansen, H. and Tarp, F. (2000). Aid and growth regressions. Journal of Development Economics, 64 (2), $547-$ 570.

Im, K.S., Pesaran M.H. and Shin Y. (2003). Testing for unit roots in heterogeneous panels. Journal of Econometrics, 115, 53-74.

Karras, G. (2006). Foreign aid and long-run economic growth: Empirical evidence for a panel developing countries. Journal of International Development 18 (1), 15-28.

Keho, Y. (2017). The impact of trade openness on economic growth: The case of Cote d'Ivoire. Cogent Economics \& Finance, 5 (1), 1-14.

Levin, A., Lin, C. and Chu, C.J. (2002). Unit root test in Panel Data: Asymptotic and finite sample properties. Journal of Econometrics, 108, 1-24. 
Marshall, M.G., and Gurr, T.R. (2013). Polity IV project: Political regime characteristics and transitions, 18002012. Center for Systemic Peace and Colorado State University. Retrieved from http://www.systemicpeace.org/polity/polity4.htm

Moreira, S.B. (2005). Evaluating the impact of foreign aid on economic growth: A cross country study. Journal of Economic Development, 30 (2), 25-28.

Morrissey, O., Gomanee, K., and Girma, S. (2005). Aid and growth in Sub-Saharan Africa: Accounting for transmission mechanisms. Journal of International Development, 17(8), 1055-1075.

Obadan, M.I. and Okojie, E.I. (2008). An empirical analysis of the impact of trade on economic growth. Jos Journal of Economics, 4 (1), 1-23.

Ouattara, B. (2006). Foreign aid and government fiscal behaviour in developing countries: Panel data evidence. Economic Modeling, 23(2), 506 - 514.

Paulino, S. (2002). Trade Liberalisation and Export Performance in Selected Developing Countries. Journal of Development Studies, 39 (1), 140-164.

Pesaran, M.H. and Smith, R.P. (1995). Estimating long-run relationships from dynamic heterogeneous panels. Journal of Econometrics, 68 (1), 79-113.

Pesaran, M.H., Shin, Y. and Smith, R.P. (1999). Pooled mean group estimation of dynamic heterogeneous panels. Journal of the American Statistical Association, 94 (446), 621-634.

Sakyi, D. (2011). Economic Globalisation, Democracy and Income in sub-Saharan African Africa: A Panel Cointegration Analysis. Proceedings of the German Development Economics Conference, Berlin 2011, No. 72.

Sakyi, D., Villaverde, J., \& Maza, A. (2014). Trade openness, income levels, and economic growth: The case of developing countries, 1970-2009. The Journal of International Trade \& Economic Development, 23(8), 123.

Wako, H. A. (2011). Effectiveness of foreign aid in sub-Saharan Africa: Does disaggregating aid into bilateral and multilateral components make a difference? Journal of Economics and International Finance, 3(16), 801-817.

Westerlund, J. and Persyn, D. (2008). Error-correction-based cointegration tests for panel data. Stata Journal, 8 (2), 232-241.

World Bank (2020). World Development Indicators. Washington, DC: World Bank.

Yanikkaya, H. (2003) Trade Openness and Economic Growth: A cross country empirical investigation. Journal of Development Economics, 72 (5), 57-89. 